\title{
VELKEY GÁBOR
}

\section{Az oktatási rendszer konszolidációjának egy lehetséges iránya}

A rendszerváltás utáni második évtized közepétől a különböző nagy állami ellátórendszerek fenntarthatatlansága és az e rendszereket újragondoló átfogó reformok szükségessége egyre szélesebb körben fogalmazódott meg hazánkban. A rendszerváltás során a legfontosabb társadalompolitikai alapkérdésekben megszülettek a szükséges döntések. Ez a kvázi konszenzus azonban nemcsak törékeny volt, hanem ekkorra el is porladt. Egyrészt a társadalom számára nem volt részleteiben ismert, így nem is válhatott elfogadottá, másrészt az utólagos politikai átértelmezések tudatosan verték szét a megegyezés maradványait.

2010-re minden érintett számára egyértelművé vált a rendszert szétfeszítő zavarok sokasága, a müködtetés, finanszírozás korábbi rendszerének fenntarthatatlansága, vagyis ahogy a témakört részletesen tárgyaló „Dinamikus egyensúlytalanság” címü 2013-ban megjelent könyvem (Velkey 2013) alcímében fogalmazok - a közoktatási rendszer szétesése.

A 2010-es parlamenti választások után az országgyülésben minősített többséget szerzett így a korábbi kormányokat gúzsba kötő kétharmados szabályok által nem korlátozott kormánypártok széles társadalmi felhatalmazásukra hivatkozva a teljes társadalmi rendszer radikális átalakításának szándékával léptek fel. Ennek értelmében az alkotmányos rendszert és az állam irányítása alá tartozó minden további részrendszert, a közigazgatást, területi igazgatást, önkormányzati rendszert, továbbá az intézményes humán közszolgáltatások mindegyikét, közöttük az oktatás, a szakképzés és a felsőoktatás rendszerét is alapjaiban változtatták meg. Mindezt széles társadalmi és szakmai konszenzus igénye nélkül, pusztán politikai legitimitásukra hivatkozva, alig néhány hónapos előkészítés és formális szakmai egyeztetések után hajtották végre. Vagyis vitathatatlanul egyoldalúan, kíméletlenül gyorsan és mélyreható változásokat eredményezve. Az elmúlt három-négy év oktatási rendszert érintő folyamatát joggal nevezhetjük felforgatásnak, miként könyvem alcímében is olvasható.

Jelen tanulmányban e szétesö, majd felforgatott rendszer konszolidációjának egy lehetséges irányát igyekszem felvázolni. Ennek során képzési szintenként haladva röviden összefoglalom a 2010 elötti legfontosabb jellemzőket és az elmúlt néhány év változásait, majd ezek alapján fogalmazok meg javaslatokat a feltárt problémák kezelésére.

\section{Az alapellátási rendszer újragondolása}

Az alapellátás 2011 előtti zavarai a következő fő okokra vezethetők vissza:

1. A csupán a valós költségek egyre csökkenő részét fedező fejkvóta alapú normatív finanszírozás.

2. Az állami feladat települési önkormányzatok révén történő ellátása és finanszírozása.

3. A térségi feladatellátás nem megfelelő szabályozása.

4. Az önkormányzati fenntartásból következő helyi közösségi ellátás-szervezési felelősség.

5. Az egyes speciális feladatokhoz, ellátásokhoz, képzési programokhoz kapcsolt egyedi normatívák meglehetősen bonyolult rendszere.

6. Az országos kisebbségi önkormányzatok, egyházak (kvázi állami intézményfenntartók) kiegészítő normatívája.

7. A bérek leértékelődése, a szolgáltatást nyújtó személyzet szükülése és a munkaterhek folyamatos emelkedése. 
Ezek az okok együttesen eredményezték azt, hogy óriási különbségek jöttek létre az állam által térítésmentesen nyújtott szolgáltatások színvonalában és az azokhoz való hozzáférésben. Túlterhelt, alulfizetett, így a túlterheltség ellenére kiegészítő jövedelem után rohangáló, munkájukra odafigyelni alig képes szakemberekkel, akiknek a tevékenységét ráadásul el sem ismeri a közvélemény (alacsony presztízs), és akiknek a rekrutációját az elmúlt bő másfél évtizedben erős kontraszelekció jellemezte, azt a felelősségteljes és komplex tevékenységet, melyet az oktatás megkövetelne, bizonyosan nem lehet színvonalasan elvégezni. Leegyszerüsítőnek és félvezetőnek tartom azonban azokat a megközelítéseket, melyek ez utóbbi problémakör rendezésének ígéretével kezelni vélik azt a komplex problémahalmazt, melyre a fentebb megfogalmazott hat pont együttesen hívja fel a figyelmet. Fordítva azonban szorosabb az összefüggés: ha nem történik meg a pedagógustársadalom gondjait feszítő problémák orvoslása, akkor még a legjobban felépített rendszer is eredményességi és müködtetési problémák tömegét fogja felmutatni.

A nemzetközi gyakorlat alapján az alapellátás szervezésében két eltérő modell különböztethető meg: az állam által, tehát központosított hatáskörben nyújtott és szervezett szolgáltatás, illetve a decentralizált, a helyi társadalom által vállalt, felügyelt és szervezett szolgáltatásszervezés. Bár többnyire a tiszta modellek a jellemzőbbek, előfordulnak átmeneti formációk. Ilyennek tekinthető a magyar rendszer is.

A hazai oktatási rendszer a rendszerváltás előtt egyértelműen a központosított, a rendszerváltás után pedig a helyi társadalom hatáskörében szervezett oktatási modell jellemzőihez állt közelebb, ez utóbbin belül pedig az intézményi szinten hozott döntések dominanciájával jellemezhető országok közé tartozott (Balázs-Palotás 2006), ahol a hatásköröket egyre nagyobb arányban üresítette ki az új évezred első évtizedének második felére már szinte kezelhetetlenné váló forráshiány. A 2011 utáni változtatások radikalizmusát jól szemlélteti, hogy az egyik szélső helyzetet jelentő modellirányból (szélsőségesen decentralizált modell) az állam által nyújtott és egyúttal szélsőségesen centralizált szolgáltatási rendszerbe léptünk át.

A 2011 elötti rendszer feltárt zavarai közül a közvetlen állami fenntartásba és központosított irányítás alá vont új rendszer elvileg szinte automatizmusszerüen kezelte az önkormányzati fenntartásból (2.), továbbá a települések erősen differenciált pénzügyi helyzetéből és a fejkvótaalapú finanszírozásból (1.) következő problémákat. Miután az alapellátás talán legtöbb zavara föképp erre a két okra volt visszavezethető, feltételezhetnénk, hogy ezzel a korábbi súlyos zavarok orvoslása és a rendszer kiegyensúlyozott fejlesztése elől elhárultak az akadályok. Sajnos azonban ez nem következett be, és nem is várható a gyors előrelépés, mert egyrészt a fennmaradó öt probléma csak részben vagy egyáltalán nem szünt meg, másrészt az önkormányzatok szerepe az infrastruktúra biztosításában megmaradt, továbbá nem oldódott az akut forráshiány, ami a színvonalas szolgáltatás nyújtását különösen személyzet biztosításában, de a tárgyi eszközök, felszereltség, továbbá az alap infrastruktúra terén is jelentősen akadályozza. A rendszer részét képező egyházi (és kisebbségi önkormányzati) kiegészítő normatíva (6.), illetve az önkormányzatok (háromezres lélekszám felett) megmaradó szerepe az infrastruktúra és az eszközök biztosításában továbbra is különbségeket eredményez az állam által garantált szolgáltatásokban, azok támogatottságában, így színvonalában, szélességében is. Ez a szabad iskolaválasztás lehetősége mellett a szolgáltatásért folyó verseny fennmaradását eredményezve a szegregációs folyamatok továbbélésének veszélyét erösíti (5.).

A 3. pontban megfogalmazott kérdéskör kezelését, vagyis az általános iskolai oktatáson kívüli további alapszolgáltatásokhoz történő hozzájutás feltételeit elvileg továbbra is térségi szinten nyújtja az állami fenntartó járási egységekre alapozódó szolgáltatásszervezése. A szolgáltatások államosításának folyamatában a korábbi rendszerek szétestek, majd az egyes 
szolgáltatóegységek (intézmények, telephelyek) szintjén kizárólag a szociális jellegü intézményi szolgáltatások (egész napos ellátás, iskolai étkeztetés, iskolaorvos) feltételrendszerét teremtették meg. A gyermekjóléti szolgáltatások továbbra is az önkormányzati szint feladatát képezik, amit jellemzően társulási formában szerveznek meg a települések. E téren az elmúlt években- a kezelendő problémahalmaz egyértelmü növekedése ellenére - elörelépés helyett egyértelmü visszalépés következett be, nemcsak a kisebb, de a nagyobb települések esetében is, amiben fontos szerepet játszott a civil szolgáltatók finanszírozásának szükítése. A pedagógiai szakszolgálatok és szakmai szolgáltatások rendszere az állami ellátás keretei között szerveződik, formálisan a feladatellátás biztosított, gyakorlatilag azonban sem a személyzet, sem a feltételrendszer nem teszi lehetővé a szükségleteknek megfelelő tartalmi ellátást. E téren tehát inkább a rendszer széteséséről, mint újjászerveződéséröl beszélhetünk. Ez a célzott normatívák rendszerének megszünésével is összefügg, hiszen a korábbi finanszírozási rendszer az ellátási szükséglet feltárásában és kezelésében tette érdekeltté a szereplőket, az új azonban csupán a legszükségesebb személyzet bérkeretének biztosítását írja elő.

Vizsgálataim szerint az önkormányzati fenntartásból következő helyi közösségi ellátásszervezési felelősség a helyi elit érdekeinek szinte korlátok nélküli érvényesülését eredményezte (4.). Az önkormányzatoktól elvont ellátásszervezési hatáskör elvileg ezt a problémát kezelné, ám a túlpolitizált, hatalmi-politikai aspirációkkal terhelt állami intézményfenntartás nem a szakszerüséget, hanem az államot kisajátító politikai és társadalmi elit érdekeit közvetíti, miközben a helyi közösségi, munkavállalói és szakmai kontroll szerepét minimálisra csökkenti.

Az (7.) új rendszer talán legsúlyosabb következményei az oktatás-nevelés intézményes szolgáltatásaiban kulcsszerepet betöltő személyzet munkafeltételeinek változásában jelentek meg. A kötelezö óraszám növekedése, a tartalmi elöírások változása, egyre merevebbé válása, az önálló kezdeményezések, kreativitás erőteljes korlátozása, a túlmunka, többletfeladat pénzügyi ellentételezésének megszünése, a féloldalasan (a pályakezdők érdemi béremelése a tapasztalt pedagógusok helybenjáratása mellett) bevezetett életpályamodell, a végtelenül centralizált rendszerből következő függőségek egyenként és összességében is nagyban akadályozzák, szinte lehetetlenné teszik a minőségi munkavégzést.

A jövőre vonatkozó fö kérdés továbbra is az, hogy a fentebb vázolt két tiszta modell közül melyik irányában fejlesztjük a napjainkban is müködési zavarok sokaságától terhelt hazai alapellátási rendszert. Megítélésem szerint, amíg a decentralizált modell működéséhez nélkülözhetetlen kiegyenlítetett területi struktúrájú és az alapellátások teljes körének finanszírozásához szükséges pénzügyi erőforrásokkal rendelkező önkormányzati rendszer nem jön létre, addig a decentralizált modell szerinti szolgáltatásszervezés súlyos, szinte kezelhetetlen kockázatokat hordoz. Bár a 2011 utáni változások a közigazgatás hazai rendszerét szintén radikálisan átformálták, az önkormányzati rendszer alapstruktúráin nem változtattak. A decentralizált rendszer teljes egészében központosított finanszírozással nem képzelhető el. A helyi közösség szolgáltatásszervezési felelössége csak közösségi életében aktív, pénzügyileg nemcsak erős, hanem önálló, szolidáris önkormányzatokkal lehet sikeres. A megfogalmazott kritikai észrevételek egyértelmüen kijelölik a továbblépés lehetséges útját, feltéve, hogy a 2011-es irányt megtartva az állami fenntartás modelljében gondolkodunk tovább. A helyi közösségi és a társadalmi (továbbá a szakmai és munkavállalói) konkroll ugyanis az állami fenntartáson alapuló modell esetében is érdemben javítható. Ehhez olyan rendszert szükséges létrehozni, mely

- a területileg érintett önkormányzatok társadalmi felügyelete mellett az iskolaszékek felépítéséhez hasonló módon szervezett, 
- a jogszabályok szerint járási szinten decentralizáltan létrehozott, saját hatáskörökkel rendelkező állami fenntartót jelent,

- a fenntartótól elkülönített intézményi költségvetést garantál.

Az egyházi képzések állami finanszírozása esetén az állami intézmények versenyhátránya csak úgy csökkenthető, ha az állam fő szempontként kezeli és mindenki számára hozzáférhetővé teszi a tehetségek differenciált gondozásához szükséges feltételeket biztosító szolgáltatásokat.

Az alapellátás megszervezésének e felvázolt modellje, tekintettel a komplex szolgáltatásokra (oktatási, szociális, közművelődési, közösségi feladatok), az integrált helyi társadalmi kapcsolatokra (egyéb helyi közösségi, közmüvelődési, felnőttképzési funkciók) és a területi léptékre, szoros rokonságot mutat a Kozma és munkatársai által felvázolt ,általános müvelődési központokkal". Az itt vázolt javaslat ugyan - a külső feltételek (önkormányzati rendszer, helyi társadalmak, közösségek állapota) és a négyévente végrehajtott „rendszerváltások” tarthatatlansága miatt - az állami fenntartás modelljének továbbvitelében gondolkodik, azonban többéves elökészítés és szerves fejlödés eredményeként könnyen átvihető a decentralizált modell irányába is, erősítve az alulról építkező, a helyi társadalom érdekeit is közvetítő rendszer pozitívumait.

\section{A középfokú oktatás és az iskolarendszerü szakképzés továbbfejlesztése}

A középfokú oktatás, képzés és intézményrendszer működési zavarai öt csomópont köré csoportosíthatók:

1. A szakirodalom nemzetközi trendekre hivatkozva rendre felveti a szelektíven építkező középiskolai intézményrendszer komprehenzív (Lóránd 1997) irányba történő módosításának kérdését (Csapó 2008). Bár ez a törekvés szakmailag sok szempontból alátámasztható, a teljes intézményrendszeren nehezen átvihető, továbbá a rendszer további dezintegrációját eredményezve bevezetése egyenesen káros lehet. A továbbfejlesztés irányát azonban e törekvéssel összhangban kellene meghatározni. A tanulók többségét érintő általános iskola utáni intézményváltás még hosszú évekig nem látszik elkerülhetőnek, miként az sem, hogy a középiskolai intézményrendszer egyes elemei ne a jelentkezők valamilyen szelekciójára épüljenek. A kulcskérdés az, hogy hány éves korban és milyen elágazásokat kínálva történik a szelekció.

2. A rendszerváltást követően a középfokú oktatás képzési idejének több lépcsőben történt növelése, a korábban párhuzamosan folyó szakmai és közismereti képzés szétválasztása és az így élesen elkülönített szakképző évfolyamok lényegében egy kísérletet jelentettek a pályaválasztás kétlépcsős rendszerének bevezetésére. A rendszer lényegét adó szabályok azonban több lépésben - elsősorban az intézmények tanulószerző és -megtartó érdekei miatt - felpuhultak, majd be is záródtak, és immár felmenő rendszerben ismét a párhuzamosan szervezett szak- és közismereti képzés jellemzi a rendszert (az érettségizettek esetében korlátozott formában megmaradt a kétlépcsős rendszer, lásd technikus képzés, érettségi utáni szakképzés). A tizennégy éves korban történő pályaválasztásban értelemszerűen sem a gazdasági szereplőknek, sem a gyakorlati képzés szervezésének, sem a kamaráknak nem lehet érdemi szerepük, vagyis munkaerö-piaci szempontból bizonyosan nem is lehet megalapozott, így a szakiskolai képzés szervezésének régi-új modellje nem jelenthet megoldást sem a hiányszakmák problémájára, sem a szakiskolai tanulók létszámának csökkenésére.

3. A képzési szint kiválasztásában két szempontnak; az általános iskolai eredmények és a felvételi esélyeknek van döntő szerepe. A képzés irányában a családi tradíciók, 
feltételezett perspektívák, szaktantárgyi eredmények a döntőek. Széles körben megfigyelhető jelenség még, hogy a magasabb iskolai végzettség presztízse felülírja a szakirányt. Erre a felül kiszélesedő képzési kínálat jó lehetőséget teremtett a felsőoktatás és az érettségit adó képzések esetében is. Részben ennek tudható be, hogy a jobb képességü tanulók egyszerüen elfogytak a szakiskolákból. A magasabb szintü képzési kapacitások szükítése és az ezáltal mesterségesen visszaszorított kereslet azonban a szelekciós mechanizmusokat nem változtatja meg, így nem is alkalmas a probléma érdemi kezelésére, az a képzés tartalmi elemeinek (általános iskolai kompetenciaalapú oktatás, a manuális képességek szerepének növekedése) újragondolását kívánja.

4. A tanulók számára hat-, tíz-, tizenkét és tizennégy éves korban is intézményválasztási alternatívát kínáló rendszer indokolatlanul bonyolult. A legkésőbb az általános iskola befejezésekor kényszerüen meghozott továbbtanulási döntés fő kérdése, hogy valójában mi alapján is történik. A hazai rendszer vállaltan két szempontot kínál fel: az elkötelezett képzés választásának lehetőségét, illetve a tanulók képességek szerinti szétválogatását. Bár a tanulók képességek szerinti szétválogatása (különösen az alacsonyabb életkorokban) oktatásszervezési és hatékonysági szempontból is vitatható, vizsgálataim és a szakirodalom is egyértelmüen azt erősítik, hogy a tanuló képességeinél lényegesen fontosabb szerepet játszanak a szelekcióban a külső, elsősorban családi, társadalmi összetevők és a gyermek által elért vagy elérhető intézményes szolgáltatások minőségi jellemzői.

5. Vizsgálataim és a szakirodalom bizonyította, hogy a TISZK-rendszer bevezetése nem hozott érdemi előrelépést a szétaprózódott képzési rendszer és infrastruktúra akkumulációjában, vagy az ellátások területi összehangolásában. Bár az RFKB-k fontos hatáskörökkel rendelkeztek a középfokú szakképzés szervezésében, sem a munkaerö-piaci szempontok érvényesítésében, sem a területi összehangolásban nem sikerült áttörést elérniük, amit a bizottságok megyei szintre telepítése és gyengített hatáskörei várhatóan a jövőben sem segítenek majd.

A középfokú oktatási intézményrendszerek nemzetközi összehasonlító elemzései (Benedek 1997, Habók-Szuchy 2007, Köpeczi 2006, Küllő és mások 2013) képzési időszak növekedésén, a képzési tartalmak bövülésén, a magasabb képzettségek munkaerö-piaci felértékelődésén és a képességek fejlesztésére koncentráló, így az egész életen át tartó tanulás feltételeinek megteremtését segítő tartalmi megújuláson kívül érdemi szerkezeti sajátosságokat nem tárnak fel. Az az építkezési modell nevezhető általában jellemzőnek, mely a tényleges pályaválasztást a későbbi életszakaszra tolja és szakmai képzési kimenet kiválasztásához közelíti. Jellemző még a téves, vagy nem megalapozott választás korrekciójának lehetővé tétele.

E nemzetközi tendenciáknak élesen ellentmond a közismereti képzés szakiskolai szükítése, a képzési idő és a tankötelezettség korának csökkentése, a párhuzamos képzés következtében aránytalanul leterhelt és a gimnáziumok tanulóival a felsőoktatásért folytatott versenyben hátrányba kerülő szakközépiskolások helyzete, valamint a „zárt pályát” eredményező korai pályaválasztás.

Mindezek fényében a hazai problémák kezelésének lehetséges módja a pályaválasztás feltolása a szakképzés megkezdéséhez. Ehhez azonban elengedhetetlenül szükséges, hogy a közismereti képző szakaszban valóban csak szakmai orientáció és pályaválasztást megalapozó képzés folyjék, és az széles körben történjen, hogy a pályaválasztás mind a képességek, mind a munkaerő-piaci folyamatok oldaláról alátámasztott lehessen. A szakiskolákra jellemző negatív szelekció korlátozása is a megelőző képzés átalakítását kívánja. A képzés irányának kiválasztása ez esetben is a megelőző szakaszban írja elő a választást megalapozó ismeretek elsajátítását és a szükséges kompetenciák kialakítását. Mindez a komprehenzív képzési 
rendszer irányába történő továbblépést jelenti, és az alapképzés legalább egy-, de inkább kétéves kiterjesztésével érhető el, vagyis több európai országhoz hasonlóan tizenhat éves korra kitolt alapképzést jelent, amin belül biztosítható az intézményen belüli képességek szerinti szelekció. A pályaválasztás tizenhat éves korra kitolva, továbbra is három irányban történhet (két éves szakiskola - speciális szakiskola -, három éves szakközépiskola és gimnázium).

A szakmai vizsgára felkészítő iskola fogalmára alapozva és a szakképzés-szervezési társulás (társaság) logikáját követve a szakképzést kizárólag e tevékenységet folytató szakiskolák végeznék. Ezek fizikai bázisa a központi képzőhely (mühely), ami a TISZKmodellnek megfelelően széles szakmacsoportot átfogó, időben előrehaladva egyre kevésbé szétaprózódott, napi ingázással elérhető térben centralizált, a csúcstechnológiát felvonultató, akár több telephelyet is müködtető létesítmény lenne. Ez lényegében a TISZK-modellnek megfelelö jövőképet jelent. A központi képzőhely biztosíthatná az érettségihez kötődő szakképzés gyakorlati képzésének fizikai bázisát is, így maga köré szervezné a szakközépiskolák hálózatát. Az alapképzés utolsó két évéhez kötődő szakmai orientációt és pályaválasztást megalapozó képzéseket a lehető legszélesebb kínálat felmutatásával a központi képzőhely és a köré szerveződő szakközépiskolák bázisán az azokban foglalkoztatott szakemberek végeznék. Szintén a központi képzőhely által szerveződne a szakközépiskolai tanulók számára is kötelező nyári üzemi gyakorlat.

Az alapképzés kitolásának fontos hozadéka a szolgáltatás decentralizációja, hisz az alapképzés intézményeiben hosszabb időt töltenének a diákok, amire a rendelkezésre álló infrastruktúra a gyermekszám és a tanulócsoportok számának évek óta tartó csökkenése miatt alkalmas (vagy könnyen azzá tehető). Az érettségit adó képzések a mérethatékonyság, a szükséges szakembergárda és az infrastruktúra alapján a kis és középvárosok szintjén racionálisan megszervezhetö, aminek nagyon fontos pozitív következményei lehetnének e városok helyi társadalmában. A szorosan vett szakképzés a közép- és nagyobb városokban szerveződne, a tanulók kihelyezett (gazdasági kamara által szervezett) gyakorlati képzése pedig lakóhelyük közvetlen környezetében, decentralizáltan lenne elérhető. A földrajzi fekvéstől függően a központi képzőhelyen (mühelyben) szervezett képzési elemek heti rendszerességgel, illetve tömbösítve is szervezhetők. A párhuzamos müvészeti képzés intézményei a jelenlegi modell szerint, a szakközépiskolák képzési rendszeréhez hasonlóan, tizenhat éves kor után lennének elérhetők és középfokú szakképzettséget adnának vagy a szakirányú felsőoktatás irányába képeznék a tanulókat. A hagyományos gimnáziumi képzéstől eltérő infrastruktúrát nem igénylö, felsőoktatás-orientált elméleti jellegü szakközépiskolákat, miután azok jelenleg is a felsőoktatás irányába képeznek, közgazdasági, informatikai, rendészeti gimnáziumként egyfajta specializált képzést nyújtva lehetne megtartani.

A javasolt változtatások a strukturális hatásokon túl az egyre centralizáltabbá váló középfokú oktatás közismereti képzéseit visszavinnék a kis- és középvárosokba. Ezzel nagyban erősítenék e városok központi szolgáltató szerepét, munkahelyeket teremtenének, az értelmiség helyben tartásával segítenék a lokális társadalmat, az intézményi infrastruktúra helyi közösségi kihasználásával pedig a közösségi, közmüvelődési, szociális, felnőttképzési feladatok magasabb szintü ellátását tennék lehetővé. A vázolt javaslatok a területi lépték és komplex szolgáltatások tekintetében nagyon hasonló az ún. müvelödési városközpont koncepciójához (Kozma 2002). A javaslatok e koncepciótól annyiban térnek el, hogy csak a középiskola közismereti képzésére vonatkoznak, illetve annyiban mások, hogy a középiskolák összehangolt kistérségi hálózata nyújtja magát a komplex szolgáltatást. A szakképző szakasz a gazdaság térbeli átalakulása, a munkaerö-piaci kapcsolatok erösítése és a hatékony szervezés miatt nagyobb területi egységeket átfogó összehangolást kíván, amit a szakközépiskolákat és szakiskolákat hálózatba szervező TISZK-ek végeznének, immár nem a 
középiskolák közötti gyermekekért folyó kizáró versenyt, hanem az együttmüködést, kooperációt előtérbe állítva. Ez a jövőkép szorosan egybecseng a „tanuló város, tanuló régió” programban, megfogalmazottakkal (Rutten és mások 2000) és az annak hazai adaptációját szorgalmazó tanulmányokkal (például Balázs 2007).

\section{Az iskolarendszerü szakmai gyakorlati képzés rendszerének átalakítása}

A szakképzés munkaerő-piaci kapcsolatait illetően a hazai rendszer kritikus elemei négy témakör köré csoportosítva foglalhatók össze:

1. A gazdasági szereplők szakképzésbe történő bevonása:

- Kutatásaim alapján a kis- és mikrovállalkozások által uralt tanulószerződéses rendszer csak erősen korlátozottan képes a munkaerő iránti kereslet közvetítésére.

- Az adatok szerint a nagyobb szervezetek részvétele a tanulószerződésekben és a megállapodás alapján folyó képzések aránya lényegesen kisebb a szükségesnél.

- A gyakorlati képzés szakképzési hozzájáruláson keresztül történő finanszírozása az eljárás időigénye, az adminisztrációs kötelmek és a bürokratikus szabályok miatt korábban szinte lebeszélt a részvételröl. Az adminisztrációs terhek és bürokratikus elöírások közelmúltban életbe léptetett oldása e téren eredményezhet elörelépést, miként a nagyobb szervezeteket kiemelten támogató új finanszírozási szabályok is.

2. A kamara irányítási és ellenörzési szerepköre:

- A kamarák az érdekeltségi-függőségi viszonyok miatt a rájuk bízott ellenőrzési feladatokat csak korlátozottan láthatják el.

- A gazdasági szereplők és a kamara érzéketlen az állami források kiáramlásával és hatékony felhasználásával szemben.

- A szakmai és vizsgakövetelmények meghatározásában és a vizsgáztatási eljárásokban növelni szükséges a kamarák szerepét, amit határozottan megjelenik a 2011 után elfogadott jogszabálycsomag is.

3. A szakképzési hozzájárulásból fizetett ún. fejlesztési támogatások intézmények közötti szóródása indokolatlanul nagyarányú volt, a lehetséges támogatás nagyobb része nem jutott el az érintettekhez. A rendszer tehát bürokratikus, kijátszható volt, ráadásul az eredeti céloknak megfelelö felhasználás sem garantálta, amiben a fenntartók szerepének növelését célzó jogszabályváltozások sem eredményeztek elörelépést. A 2011 után mindezek alapján indokoltan törölték ezt az eszközt a szakképzés finanszírozásából. A kieső források pótlása azonban egyelőre elmaradt.

4. Az adatok és a folyamatok alapján korábban a felsőoktatás és a felsőfokú szakképzés egyre erősödő konkurenciát jelentett a szakképzés számára. A felsőoktatási és a szakképzési törvények 2011 után kezelték a párhuzamosságokat, a két képzési irány élesen elvált egymástól, egyelőre azonban a felsőfokú szakképzés szerepe a gyakorlatigényes felsőoktatási képzési irányok esetében sem vált népszerüvé.

A nemzetközi gyakorlat alapján a szakképzés szervezésének két eltérő logikája különböztethető meg (Velkey 2010); a gazdasági szereplök (majdani foglalkoztatók) és szervezeteik (kamara, ágazati szakmai szövetség) által vállalt, felügyelt és szervezett szolgáltatás, és az állam által nyújtott és szervezett szolgáltatás rendszere.

A gazdasági szereplőkre és szervezeteikre alapozó szakképzés a tradicionális tanoncképzés logikáját viszi tovább. A németországi duális képzési rendszer a szakképzés egy szegmensében érvényesíti ezt a logikát, a piac szereplői által nem felvállalt képzési területeken azonban ott is az állami képzésszervezés érvényesül. E kettős képzésszervezési logika a kontinentális Európa több országában kisebb-nagyobb eltérésekkel szintén megfigyelhető. A skandináv és az angolszász országokban inkább az állami (vagy tartományi, 
illetve területi önkormányzati) szolgáltatásszervezés a jellemző. A szoros gazdasági kapcsolatok igénye ott is megjelenik, de nem átadott feladatként, hanem a képzés intézményes szereplöinek felelősségében.

A gazdasági szereplők által közvetlenül szervezett szakképzési logika lényege, hogy a gazdaság szereplői képezik ki saját maguk számára a szükséges munkaerőt. Ezt jellemzően a kamara (vagy az adott ágazatba tartozó munkáltatókat tömörítő szervezet, szövetség) által fenntartott szakképző intézményekben és a fenntartó szervezet finanszírozásával oldják meg. A kamarai rendszer kötelező kamarai tagságot és a finanszírozás alapjául szolgáló forrásokat feltételez (tagdíjak, egyéb bevételek, állami támogatás). Miután a képzés fedezetét jelentő források a kamara forrásai (a kamara a költségviselő), ezért a képzési kapacitások és a képzési irányok meghatározásakor is hatékonyságra törekszik, igyekszik elkerülni a felesleges, tehát munkaerő-piaci igénnyel (konkrét foglalkoztatási tervvel) nem alátámasztott képzéseket. Miután a képzéseket szervező kamara pontosan ismeri a tagjai közül kikerülö foglalkoztatók igényeit, a képzés megszervezésekor a hangsúlyt a használható tudásra helyezi.

A kamarai rendszerben gyakorlatilag minden tanuló tanulószerződéssel rendelkezőnek tekinthető, amihez egyfajta továbbfoglalkoztatási kötelezettség is társul. A képzés fizikai bázisa korábban szorosan kötődött a termelőtevékenységhez, később attól részben elvált, az utóbbi évtizedekben pedig mind a képzések irányát, mind a fizikai elhelyezkedést illetően egy gyors és érdemi koncentrálódás figyelhető meg, aminek eredményeként nagy, térségi, komplex képzési szolgáltatást nyújtó bázisok jöttek létre.

Miután a kamara csak az általa érzékelhető (tagjai által közvetített) munkaerőigény kielégítésére törekszik, a diákok egy része - a technikai, technológiai fejlődés eredményeként egyre nagyobb része - nem tud belépni e képzési rendszerbe. Számukra az állam saját vagy önkormányzati (városi, térségi) fenntartású intézményekben kínál képzéseket, értelemszerüen elsősorban azokban a szakképzési irányokban, ahová a kamarai rendszer nem képez. E képzések munkaerő-piaci megfelelése lényegesen kétségesebb, mint a kamarai bázison szervezetteké. Bizonyos szempontból szociális alapú képzésként is felfoghatók, vagyis céljuk a társadalomból történő kikerülés, marginalizálódás esélyének csökkentése, és az elhelyezkedéshez szükséges általános, konvertálható tudáselemek, szemlélet, képességek elsajátítása, a korábban felhalmozott hátrányok kompenzálása.

Az állami szakképzésszervezés legfontosabb sajátossága, hogy a képzést adóbevételekből finanszírozzák, és a szolgáltatást is állami (önkormányzati) fenntartású intézmények nyújtják. Az elmúlt években e rendszernél is érdemi koncentrációs folyamat játszódott le, itt is nagy, térségi, komplex képzési bázisok jöttek létre. Miután ebben az esetben - a kamarai rendszerrel szemben - a képzés szervezési modelljéből nem következik automatikusan a munkaerö-piaci megfelelés, ezért az intézmények szoros kapcsolatokat alakítanak ki a gazdaság szereplöivel. ${ }^{1}$ A kapacitások szabályozásában sem érvényesülhet a munkaeröpiac közvetlen megrendelöi szerepe, így azt központilag határozzák meg és bontják le területi egységek szerint. E rendszerekben jellemzően nem tanulószerződéssel, hanem a képző intézmény szervezésében, ciklikusan vesznek részt kihelyezett üzemi gyakorlaton a tanulók. Az intézményi tanmühelyben sajátítják el a legfontosabb ismereteket, az üzemi gyakorlat csak kiegészíti ezeket, és alkalmat teremt a munkaadóknak, hogy megismerjék és kiválasszák leendő alkalmazottaikat. Gazdasági kapcsolatok, üzemi gyakorlóhelyek nélkül általában nem indítanak képzéseket.

A jelen felé közeledve a két modell egyre hasonlóbbá válik, mely irány megegyezik a nálunk is megjelenő TISZK-modell lényegével. Mindenhol egyértelmű koncentrációs

${ }^{1}$ Ennek módszerében lényeges különbségek vannak, ami miatt e rendszer szórása a munkaerő-piaci megfelelés tekintetében is nagyobb a kamarainál. 
folyamat figyelhető meg, illetve kölcsönösen átvették a másik modell néhány fontos részelemét; a felelősség, irányítás, finanszírozás, gazdasági kapcsolatok szervezése tekintetében azonban továbbra is eltérő logikát követnek. A két modell fejlődése abból a szempontból azonban teljesen megegyező, hogy egyszerre szolgálják az iskolarendszerü szakképzést és a felnőttképzést.

A két modell legfontosabb jellemzőinek vázlatos áttekintése alapján megállapítható, hogy a hazai szakképzési rendszerben a gyakorlati képzés tanulószerződései a kamarai képzési logikához igazodnak, megmarad azonban az állami rendszer dominanciája a finanszírozásban, a megállapodás alapján végzett gyakorlati képzésben és a szakmai elmélet oktatásában. Ráadásul a két szervezési logika nálunk nem legalább részben elkülönült intézményrendszer formájában jelenik meg, hanem az egyes intézményeken, képzési programokon belül egyszerre kellene érvényesülniük. A hazai rendszer tehát e rövid áttekintés alapján is egyfajta hibrid modellként értelmezhetö. A hibrid modell azonban nem müködhet jól, ha a kamarai elem esetében a kamara nem költségviselö, az állami rendszer pedig pazarló lesz, ha a finanszírozó legfeljebb bürokratikus akadályokkal korlátozhatja a forráskiáramlást.

A rendszer továbbfejlesztésében ezért vizsgálataim szerint a következő szempontoknak kellene meghatározó szerepet betölteniük:

- Tiszta, egyértelmü érdekeltségi és ellenőrzési szerepkörök kialakítása.

- A duális modellben érvényesülő automatizmusszerü keresletszabályozás minél szélesebb körben történő érvényesítése.

- A gazdasági szereplők részvételének szabályozott növelése a gyakorlati képzés szervezésében.

- A felnőttképzés és a szakképzés összekapcsolt fejlesztése.

A szabályozás olyan irányú (további) módosítására van tehát szükség, mely csökkenti a tanulók kiszolgáltatottságát, erősíti az ellenőrzést, a szervezésben (és nem az ellenőrzésben) növeli a kamarák (illetékes szakmai szövetségek) szerepét, pénzügyi alapú érdekeltséggel korlátozza az öncélú képzést, és növeli a gazdaság szereplőinek részvételét a gyakorlati képzésben. E felvetések a rendszer továbbfejlesztését célozzák, vagyis nem vitatják a szakképzésszervezésnek azt az alapvető irányát, mely a gazdasági szereplök bevonását mind a képzés tartalma, mind a képzés iránti munkaerő-piaci kereslet szempontjából fontosnak tartja. A továbbfejlesztés kívánatos iránya vizsgálataim alapján a következőkben foglalható össze:

- A nemzetközi tapasztalatok alapján minden jól müködő rendszer evidens jellemzője, hogy ugyanaz a szerv felel a képzés egészének megszervezéséért és finanszírozásáért, ráadásul a tanuló is e szerv felé számol el tevékenységével, vagyis kihelyezett képzés esetén az ellenőrzésért és a tanuló képzéséért felelős szereplőnek azonosnak kellene lenni.

- Ha a tanuló szerződéses viszonyban csak az intézményével van (tanulói jogviszony), akkor az intézmény felelősségi körébe kell tartoznia minden tanulónak járó szolgáltatásnak, így a gyakorlati képzés megszervezésének és finanszírozásának is, függetlenül attól, hogy azt saját tanmühelyében vagy más szereplök bevonásával oldja meg. Ha a tanuló szakképzéséért felelős intézmény köt szerződést a külső gyakorlatot végző gazdasági szereplővel, értelemszerủen megszünik a tanuló kiszolgáltatottsága.

- Ha az intézmény nem közvetlenül az egyes gazdasági szereplőkkel, hanem a területileg illetékes, gazdasági szereplőket összefogó kamarával (illetékes szakmai szövetséggel) köt megállapodást, és a szolgáltatás ellenértékét is e szervezet kapja meg, azonnal érdekeltté válik a képzés hatékony megszervezésben. Ekkor a képzésben részt vevő gazdasági szereplőt a közöttük létrejött szerződés értelmében a kamara közvetíti az intézmény felé, így a kamara vállalja a felelösséget is a nyújtott szolgáltatásért. 
- Amennyiben az intézmény csak kamarai szerződéssel alátámasztott képzést indíthat és legfeljebb olyan volumenben, amelyben a kamara biztosítani tudja a központi szabályokban előírt, kizárólag gazdasági szereplők által végezhető modulokat, a képzési kínálat meghatározásában megjelenhet az automatizmus-szerü munkaerő iránti keresletközvetítés. Mindez lényegesen megnövelné a kamara szerepét a gyakorlati képzés szervezésében.

Úgy vélem, hogy a megfogalmazott konkrét javaslatok nagyon sok felvetett kérdésre választ adnak, és alapvetően összhangban vannak az elmúlt évek széles szakmai körben megfogalmazott változtatási javaslataival is. Egyes elemeikben gyorsabb és radikálisabb, másokban megfontoltabb és konfliktuskerülőbb változtatást vetnek fel. Számításokat, becsléseket az áttekintett teljes képzési rendszer forrásszükségletére vonatkozóan e munka keretei között nem végeztem, de - az evidens ellátási hiányokat leszámítva - a jelenlegi bérszínvonal esetén, melynek érdemi megemelését azonban a rendszer egészének működése szempontjából kulcsfontosságúnak gondolom, feltehetően nem lenne érdemben magasabb az elmúlt években e célra költött forrásoknál.

\section{Hivatkozott irodalom:}

Balázs É. (2007): A versenyképesség területi és társadalmi összefüggései. In: Közoktatás és versenyképesség. Hatékonyság és minöség: aktuális kérdések a hazai közoktatásban. (szerk. Simon M., Kósa B.) Oktatáskutató és Fejlesztő Intézet, Budapest, 29-43. p.

Balázs É., Palotás Z. (2006): A közoktatás irányítása. In: Jelentés a magyar közoktatásról 2006 (szerk. Halász G., Lannert J.) Országos Közoktatási Intézet, Budapest, 55-104. p.

Benedek A. (1997): Szakképzés-politika európai kitekintésben. Budapesti Müszaki Egyetem, Magyar Szakképzési Társaság, Nemzeti Szakképzési Intézet, Budapest.

Csapó B. (2008): A magyar iskolarendszer adaptációs problémái. A tudás minősége. In: Közoktatás, iskolai tudás és munkapiaci siker. (szerk: Fazekas K.) MTA Közgazdaságtudományi Intézet, Budapest, 113-130. p.

Habók A., Szuchy R. (2007): A szakképzés helyzete az Európai Unióban. Új Pedagógiai Szemle 2. 55-63. p.

Kozma T. (2002): Határokon innen és határokon túl. Regionális változások az oktatásügyben, 1990-2000. Oktatáskutató Intézet, Új Mandátum Könyvkiadó, Budapest.

Küllő J., Bajnai B., Komáromy D., Lovász A., Márk L., Simonocits G. (2013): Foglalkoztatási csodák Európában. In: Trendek és elörejelzések. Munkaerö-piaci prognózisok készitése, szerkezetváltás a munkaerőpiacon. (szerk.: Fazekas K., Varga J.) MTA KRTK Közgazdasági Tudományi Intézet, Budapest, 71-112. p.

Loránd F. (1997): Az egységes iskola. Új Pedagógiai Szemle 1997. 1. 3-20. p.

Rutten, R., Bakkers, S., Boekema, F. (2000): The analysis of learning regions: Conclusions and research adenda. In: Knowledge, innovation and economic growth. (eds: Boekema, Morgan, Bakkers, Rutten) Chetenham, UK, Northampton USA.

Velkey G. (2010): A képzési hozzájárulás és a szakképzési alaprész felhasználásának területi és strukturális jellemzöi, a szabályozás változásának következményei és továbbfejlesztésének javasolt irányai - Foglalkoztatást elösegitö munkaügyi kutatások (OFA Kutatási évkönyv 5.) OFA, Budapest, 59-72. p.

Velkey G. (2013): Dinamikus egyensúlytalanság (A hazai közoktatási rendszer szétesése, felforgatása és a konszolidáció esélye) MTA KRTK RKI, Pécs-Budapest-Békéscsaba, $213 \mathrm{p}$. 